\title{
Learning Microeconomics during the Pandemic: Does Digital Platform Management Matter?
}

\author{
Inaya Sari Melati ${ }^{1}$, Harnanik ${ }^{2}$ \\ \{inaya.sari@mail.unnes.ac.id ${ }^{1}$ \} \\ Universitas Negeri Semarang, Indonesia ${ }^{1,2}$
}

\begin{abstract}
This study aimed to analyze how student engagement affected their satisfaction, and to describe the comparison of student engagement and student satisfaction between Microeconomics online classes based on digital platform management. Two compared classes were distinguished in terms of digital platform variance. Using a quantitative approach, this study included 88 students from both classes who answered the online Likert Scale questionnaire after finishing their online Microeconomics classes during the Covid19 pandemic. The results showed that student satisfaction and student engagement were higher if the class combined different digital platforms. However, some components of student engagement namely peer-to-peer support, student-lecturer communication, and self-learning management were not intervened by digital platform management. Meanwhile, student engagement had a strong effect to student satisfaction during online learning. The findings implicated that digital platform management was important to increase student satisfaction and student engagement in online learning but it had not changed student willingness to communicate or their learning attitude. Therefore, the related factors affecting them need to be explored more to optimize online learning benefits.
\end{abstract}

Keywords: Digital Platform, Microeconomics, Student Satisfaction, Student Engagement, Online Learning

\section{Introduction}

Covid-19 first appears in Wuhan, Hubei province, China in December 2019, which then spread to almost all countries in the world. That is why WHO establishes Covid-19 as a global pandemic. Recent data as of June 22, 2020, shows that this pandemic has spread to 216 countries with the number of infected cases reaching 8,860,331 people and death cases reaching 465,740 people [1]. One of the sectors that is directly affected by the policy of social restrictions is the education sector. The closure of the school is intended to reduce the risk of children and adolescents infected by the virus, as well as reduce opportunities for them to spread the virus to people who are vulnerable to the virus in the family or community.

Table 1. Number of countries by information status as of 6/8/2020

\begin{tabular}{lc}
\hline Closed & 133 \\
\hline Closed (in select area) & 4 \\
\hline Seasonal school closures & 1 \\
\hline Open with limitations & 50 \\
\hline Open & 7 \\
\hline
\end{tabular}

Source: www.worldbank.org, 2020. 
Closing schools requires educational institutions to innovate in the learning process so that class discontinuity does not occur by conducting distance learning or online learning. This online learning is carried out by utilizing the use of media and technology that enables communication and information exchange during the learning process to continue even from a distance. Dixson [2] stated that one of the main components in effective online learning was student involvement. Likewise, Chen et al. [3] argued that there was a positive relationship between the use of learning technology, student involvement and learning outcomes. The use of technology in online learning increases student involvement through increased communication and interpersonal relationships between students [4]. Meanwhile, Alqurashi [5] argued that student satisfaction was a key element for evaluating the implementation of online learning.

Convenience is the highest reason for achieving satisfaction [6]. Callaway [7] found that students in the learning system were satisfied with the quality and convenience of traditional teaching, while students in the online learning environment were satisfied with the quality of learning, but not with the convenience of online teaching. This convenience is influenced by the actions of lecturers in online lectures [8] where it is one indicator of student engagement. Even in Gray and DiLoreto [9] research, student engagement was claimed to be able to be a partial mediator between the effects of the presence of instructors on student satisfaction. Then the first hypothesis compiled in this study is as follows:

H1: there is an effect of student engagement on student satisfaction in online Microeconomics classes.

Mustafa [10] stated the success of online learning also depends on the availability of infrastructure (adequate internet network) and access to distance learning tools. Learning activities can be delivered through broadcast media (tv and radio), social media and other digital platforms (zoom, etc.). UNESCO (2020) categorizes various educational platforms based on distance learning needs and their functions as circuits: (i) digital learning management system, this platform allows to open online classes that support learning activities, discussions, and assessments such as Edmodo, Google Classroom, Schoology etc. (ii) Systems built for use on basic mobile phones, such as Cell-Ed, Eneza Education, Funzi, KaiOS, Ubongo and Ustad Mobile. (iii) Systems with strong offline functionality, platforms that allow for offline access such as the Hummingbird, Rumie, and Ustad Mobile. (iv) Massive Open Course (MOOC) Platforms, such as Alison, Canvas Network, Udemy Coursera, etc. (v) self-directed learning content, such as Duolingo, British Council, and Khan Academy. (vi) Collaboration platforms that support live-video communication, platforms that allow for video conferencing with many participants such as Hangouts Meet, Skype, Teams, WhatsApp and Zoom.

Cacheiro-gonzalez [11] in his research stated that digital learning platforms increased learning independently $(86.5 \%)$, facilitated the availability of subject matter $(81.1 \%)$, and supported interaction between different agents in the course (78.4\%). Kurucay and Inan [12] who thought that learning platforms were a means to independently manage learning content, activities and evaluations and enable communication with lecturers and colleagues.

In this long-term online lecture, we use tools in the form of a digital platform, the pedagogical ability of teachers can no longer be displayed directly, but must be reflected in their ability to manage digital platforms. Meanwhile, many studies have found that the use of technology has little effect on learning [13] because it is actually instruction or pedagogy that creates change in student learning processes [14]. Cartner and Hallas [15] argued that online classroom activities will ultimately lead teachers to question their own understanding of 
pedagogical practices when reflecting and this brings conceptual changes to their behavior in teaching using social media, or in the context of this research is the online learning media.

Meanwhile, student engagement in the context of online learning is influenced by various factors. The results of the study by Lee, Song and Hong [16] showed that student engagement in online learning consisted of six factors (1) psychological motivation; (2) peer collaboration; (3) cognitive problem-solving; (4) interactions with instructors or instructors; (5) community support; and (6) learning management. The first is psychological factor, which represents students' thoughts and feelings, such as motivation, expectations and interests related to what is learned in online learning. Second, peer collaboration factor tends to be activities where students discuss the knowledge learned. Third, cognitive problem solving is defined as the process of acquiring, understanding, and utilizing knowledge. Fourth, interactions with instructors have meaning related to behavioral involvement where students communicate with teachers online. This interaction includes asking questions, discussing the contents of the lesson, additional assistance is considered to be the most important factors of student involvement in online learning. Fifth, community support factor, it is related to the psychological state of students, such as bonding or a sense of brotherhood that is formed between students in the class. Sixth, learning management, this emphasizes behavioral involvement. Students manage learning independently and actively participate during online learning. This factor is more directed at students in managing time, place, and environment in order to create the desired online learning atmosphere such as avoiding distractions by placing yourself in a quiet room, and planning a study schedule.

It is suspected that differences in digital management platforms in the online learning process will result in differences in student satisfaction and engagement in the learning process. On the other hand, the Microeconomics class was chosen as the sample in this study because it was considered to have material with complete characteristics, including understanding concepts, calculations, drawings and graphics. The characteristics of this complete course are expected to enrich the analysis in this study. Then the second and third hypothesis compiled in this study is as follows:

$\mathrm{H} 2$ : There is a difference in student engagement between online class that uses varied digital platforms and online class that only uses one digital platform.

$\mathrm{H} 3$ : There is a difference in student satisfaction between online class that uses varied digital platforms and online class that uses only one digital platform.

\section{Research Methods}

This research is an experimental research with a quantitative approach. The population included 218 international class students majoring in Economic Education, Universitas Negeri Semarang who takes Microeconomics classes online in semester 2. The non-probability sampling used in this study is the purposive sampling technique. The sample classes were chosen based on the same number of students and the same average ability (proven by the pretest given in the beginning of the class). The other consideration is the same teaching team of lecturers. Based on all criteria, the study sample are Office Administration Class A and Class B with 44 students in both classes.

Online learning in Microeconomics class in both classes is designed with a different digital management platform. In Class A, various digital platforms are used such as Google Classroom, YouTube, Podcast, and e-learning systems by the internal campus during learning (16 meetings) 
by taking into account the characteristics of the material presented. Meanwhile, in the Class B, only one digital platform is used, namely Google Classroom. Although the digital platforms are different, the actual content presented during learning is the same, namely the provision of material in the form of files, video links, assignments and discussions.

At the end of the semester, students from both classes were asked to fill out questionnaires to measure student engagement and satisfaction levels during Microeconomics online lectures. Student engagement indicators includes (1) psychological motivation; (2) peer collaboration; (3) cognitive problem solving (cognitive problem solving); (4) interactions with instructors; (5) community support; and (6) learning management. The questionnaire is designed with a Likert scale with 5 options, namely strongly agree, agree, neutral, disagree and strongly disagree. Data from the two classes are then analyzed by using regression analysis and independent t-test.

\section{Results and Discussion}

Online Microeconomics lectures in Class A and B each has the same number of meetings, namely 16 times, including 14 meetings, 1 mid-term test and 1 final test, all of which are designed online. The target material is also the same, which consists of 7 chapters of discussion on Microeconomics. The content of the material is also the same, which includes material in the form of power points, videos and assignments. Details of the digital platform differences used can be seen in Table 2 .

Table 2. Digital Management Platforms

\begin{tabular}{|c|c|c|c|c|}
\hline No. & Chapters & Materials & Class A & Class B \\
\hline 1. & $\begin{array}{l}\text { The scope of } \\
\text { Microeconomics }\end{array}$ & Material in power point & Elena & $\begin{array}{c}\text { Google } \\
\text { Classroom }\end{array}$ \\
\hline \multirow{5}{*}{2.} & \multirow{5}{*}{$\begin{array}{l}\text { Demand, Supply and } \\
\text { Market Balance }\end{array}$} & Material in power point & Elena & \multirow{5}{*}{$\begin{array}{l}\text { Google } \\
\text { Classroom }\end{array}$} \\
\hline & & Learning video & YouTube & \\
\hline & & Assignments & Google Classroom & \\
\hline & & Assignment reflection & YouTube & \\
\hline & & Discussion & Telegram & \\
\hline \multirow{5}{*}{3.} & \multirow{5}{*}{ Elasticity } & Material in power point & Elena & \multirow{5}{*}{$\begin{array}{l}\text { Google } \\
\text { Classroom }\end{array}$} \\
\hline & & Learning video & YouTube & \\
\hline & & Assignments & Google Classroom & \\
\hline & & Assignment reflection & Spotify (podcast) & \\
\hline & & Discussion & Telegram & \\
\hline \multirow{5}{*}{4.} & \multirow{5}{*}{$\begin{array}{l}\text { Consumer Behavior } \\
\text { Theory }\end{array}$} & Material in power point & Elena & \multirow{5}{*}{$\begin{array}{l}\text { Google } \\
\text { Classroom }\end{array}$} \\
\hline & & Learning video & YouTube & \\
\hline & & Assignments & Telegram & \\
\hline & & Assignment reflection & YouTube & \\
\hline & & Discussion & Telegram & \\
\hline \multirow{5}{*}{5.} & \multirow{5}{*}{$\begin{array}{l}\text { Producer Behavior } \\
\text { Theory }\end{array}$} & Material in power point & Elena & \multirow{5}{*}{$\begin{array}{l}\text { Google } \\
\text { Classroom }\end{array}$} \\
\hline & & Learning video & YouTube & \\
\hline & & Assignments & Google Classroom & \\
\hline & & Assignment reflection & Telegram & \\
\hline & & Discussion & Telegram & \\
\hline \multirow{3}{*}{6.} & \multirow{3}{*}{ Production cost } & Material in power point & Elena & \multirow{3}{*}{$\begin{array}{l}\text { Google } \\
\text { Classroom }\end{array}$} \\
\hline & & Learning video & YouTube & \\
\hline & & Assignments & Elena & \\
\hline
\end{tabular}




\begin{tabular}{|c|c|c|c|c|}
\hline No. & Chapters & Materials & Class A & Class B \\
\hline & & Assignment reflection & Telegram & \\
\cline { 3 - 4 } & & Discussion & Telegram & \\
\hline \multirow{4}{*}{7.} & \multirow{4}{*}{ Market Structure } & Material in power point & Elena & \multirow{3}{*}{ Google } \\
\cline { 3 - 4 } & & Learning video & YouTube & Classroom \\
\cline { 3 - 4 } & & Assignments & Google Classroom & \\
\cline { 3 - 4 } & & Assignment reflection & Google Classroom & \\
\cline { 3 - 4 } & & Discussion & Telegram & \\
\cline { 3 - 4 } & & & &
\end{tabular}

In Table 2 it can be seen that in class A the digital platform used during learning varies greatly, adjusting to the main characteristics of the learning media that you want to display. For example, if a lecturer wishes to submit material in the form of video, he chooses to upload it on YouTube rather than on other platforms, because uploading in the form of video is more popular on YouTube than on other digital platforms. Likewise, discussion forums are mostly carried out via Telegram, which is a popular chat forum among students. Whereas in class B, only one digital platform is used, namely Google Classroom, ignoring the characteristics of the learning material used.

\subsection{Effect of Student Engagement on Student Satisfaction}

Table 3. Descriptive Statistics

\begin{tabular}{lccccc}
\hline & $\mathrm{N}$ & Minimum & Maximum & Mean & Std. Deviation \\
\hline Satisfaction A & 44 & 2.50 & 5.00 & 4.2727 & .69428 \\
\hline Satisfaction B & 44 & 2.50 & 5.00 & 3.6477 & .57647 \\
\hline SE_A & 44 & 56.00 & 115.00 & 93.7045 & 12.00112 \\
\hline SE_B & 44 & 66.00 & 106.00 & 85.8636 & 11.21376 \\
\hline
\end{tabular}

From Table 3 it can be observed that the mean score of student satisfaction in class A (4.27) is higher than class B (3.64) with a difference in score reaching 0.63. Likewise, student engagement in class A (93.70) is higher than class B (85.86) with a score difference reaching 7.84. This indicates a close correlation between satisfactions with student engagement. This indication is confirmed in the correlation test that has been conducted with the result that the correlation between student satisfaction and student engagement reaches $76.60 \%$. Meanwhile, the result of the regression test shows that student engagement has a positive and significant effect on student satisfaction with a P-value of 0.776 and a significance of $0.000(\alpha 0.05)$. Thus, $\mathrm{H} 1$, which states that there is an effect of student engagement on student satisfaction in online Microeconomics classes, is accepted.

This indicates that students are actively involved in learning which has a good effect on student satisfaction. Students who are actively involved and participate in learning will build good relationships. So, they will feel accepted, supported, and involved in that environment. In addition, they will gain experience and form commitments that result in low desire to leave learning. The results of this study support research conducted by Luo, Xie \& Lian [17] which suggested that student engagement consisting of emotional, behavioral, and cognitive engagement had a significant positive effect on student satisfaction. This shows that students who have higher motivation will involve themselves in terms of cognitive, emotional, and behavior in the learning process. Cheong and Ong [18] student engagement systems that involve students in discussion, collaboration with others on projects or assignments, and creating ideas, and solutions to solve a problem will help develop their thinking habits. This experience will gradually increase self-capacity, which will have an effect on increasing satisfaction. 


\subsection{Comparison of Student Engagement in Online Microeconomics Classes based on Differences in Digital Management Platform}

Independent T-Test is conducted on both classes after the online learning period is complete. Testing this difference is carried out in two stages, namely testing differences in student engagement in general and testing the differences of each indicator of student engagement separately. The prerequisite test is carried out by using the Levene's Test in which class A and class B results are declared homogeneous ( $\mathrm{Sig}>0.05$ ). Homogeneity test data and t-test can be seen in Table 4.

Table 4. Results of Independent Samples T-Test

\begin{tabular}{|c|c|c|c|c|c|c|c|c|c|}
\hline & \multicolumn{3}{|c|}{$\begin{array}{c}\text { Levene's Test } \\
\text { for Equality of } \\
\text { Variances } \\
\end{array}$} & \multicolumn{6}{|c|}{ t-test for Equality of Means } \\
\hline & \multirow[t]{2}{*}{$\mathrm{F}$} & \multirow[t]{2}{*}{ Sig. } & \multirow[t]{2}{*}{$\mathrm{t}$} & \multirow[t]{2}{*}{ df } & \multirow[t]{2}{*}{$\begin{array}{l}\text { Sig. (2- } \\
\text { tailed) }\end{array}$} & \multirow[t]{2}{*}{$\begin{array}{c}\text { Mean } \\
\text { Difference }\end{array}$} & \multirow{2}{*}{$\begin{array}{l}\text { Std. Error } \\
\text { Difference }\end{array}$} & \multicolumn{2}{|c|}{$\begin{array}{l}95 \% \text { Confidence } \\
\text { Interval of the } \\
\text { Difference }\end{array}$} \\
\hline & & & & & & & & Lower & Upper \\
\hline Motivation & .630 & .429 & 3.875 & 86 & .000 & 2.38636 & .61590 & 1.16199 & 3.61074 \\
\hline Collaboration & .090 & .765 & 1.745 & 86 & .084 & 1.27273 & .72917 & -.17681 & 2.72227 \\
\hline Problem Solving & 1.032 & .313 & 3.149 & 86 & .002 & 1.81818 & .57738 & .67039 & 2.96597 \\
\hline Interaction & .012 & .914 & 1.340 & 86 & .184 & .43182 & .32229 & -.20887 & 1.07251 \\
\hline Community & .047 & .828 & 2.982 & 86 & .004 & 1.18182 & .39626 & .39407 & 1.96956 \\
\hline Management & .046 & .831 & 1.930 & 86 & .057 & .84091 & .43564 & -.02511 & 1.70693 \\
\hline Student Eng. & .302 & .584 & 3.167 & 86 & .002 & 7.84091 & 2.47614 & 2.91851 & 12.76331 \\
\hline
\end{tabular}

In general, descriptive data show the mean score of student engagement in class A is higher than class B with a total difference of 2.38. This difference is confirmed statistically on the results of the different tests in Table 4 . The t-count value of the student engagement variable is 3.167 with a significance (2-tailed) of 0.002 , which has a significance of less than 0.05 . This indicates that $\mathrm{H} 2$ is accepted, namely there is a difference in student engagement between class A using a varied digital platform and class B using only one digital platform.

The variety of digital platforms really allows students to learn and interact in various ways so in the implementation, students will also face challenges, which are required to solve problems both independently and in groups supported by how students organize their learning. As a result, students are increasingly skilled both in terms of cognitive and attitude in dealing with obstacles both within the scope of learning and outside the scope of learning. Thus, students in this class will be more involved than students in the class using only one digital platform.

The results of this study support research conducted by Chakraborty and Nufakho [19] which explained that student engagement in online learning could be strengthened by using appropriate technology to deliver the right material (right technology). Casey and Jones [20] stated that the use of video technology effectively increased student engagement, which had an impact on students' understanding of the material. In addition, video technology helps students who feel minority or marginalized become more active and involved in learning. Bledsoe and Simmerok [21] suggested the use of online multimedia in learning allowed students to learn important concepts with the help of texts, photos, videos, and various features for communicating to increase student engagement, even though learning was carried out remotely. 
In terms of each indicator of student engagement, three indicators in the form of psychological motivation, cognitive problem-solving and community support are consistent with the results of the different tests of student engagement in general, namely there is a significant difference between the use of varied digital learning platforms with online learning only using one digital platform. However, the other three indicators namely peer collaboration, interactions with instructors, and learning management do not show significant differences from the variations of digital platforms in online learning.

Table 5. Mean Difference in Indicators of Student Engagement

\begin{tabular}{lccccc}
\hline & Group & $\mathrm{N}$ & Mean & Std. Deviation & Std. Error Mean \\
\hline \multirow{2}{*}{ Motivation } & 1.00 & 44 & 20.1818 & 2.94344 & .44374 \\
\cline { 2 - 6 } Collaboration & 2.00 & 44 & 17.7955 & 2.83319 & .42712 \\
\cline { 2 - 6 } & 1.00 & 44 & 24.2045 & 3.52783 & .53184 \\
\hline \multirow{2}{*}{ Problem Solving } & 2.00 & 44 & 22.9318 & 3.30889 & .49883 \\
\cline { 2 - 6 } Interaction & 1.00 & 44 & 19.1364 & 2.74151 & .41330 \\
\cline { 2 - 6 } & 2.00 & 44 & 17.3182 & 2.67436 & .40318 \\
\hline \multirow{2}{*}{ Community } & 1.00 & 44 & 6.5909 & 1.52983 & .23063 \\
\hline \multirow{2}{*}{ Management } & 2.00 & 44 & 6.1591 & 1.49329 & .22512 \\
\hline & 1.00 & 44 & 11.6364 & 1.93007 & .29097 \\
\hline & 2.00 & 44 & 10.4545 & 1.78436 & .26900 \\
\hline
\end{tabular}

Although descriptively, the mean on all student engagement indicators in class A (varied digital platform) is greater than in class B (one digital platform), statistically there are some indicators that cannot be claimed to have significant differences. Peer collaboration does not show a difference, because both class A and class B are assigned by the same type of task, namely individual assignments, so they do not provide space for students to collaborate with their classmates. Louder et al. [22] strengthened this finding with the results of their research which identified that students who studied online were more likely to expect learning support by interacting with their lecturers directly rather than collaborating or interacting with classmates.

Interaction with instructors (in this case, lecturers) also does not describe any significant differences. Bernard et al. [23] found the importance of three kinds of interactions during the online learning process, namely interaction between students, interaction with instructors and interaction with material content. Lecturers as instructors in online lectures in class A and B has the same goal of stimulating, maintaining and increasing student interest in learning. The method used is the same, namely in discussion forums with any chat platform used. Therefore, it is not surprising that in this case the difference between class A and B is not significant.

Indicators of student learning management in class A are also not different from class B. This happens because learning management is more affected by the individual's learning character, regardless of what digital platform is the learning facility. Moreover, audio-visual learning content provided in class A and class B is the same. Learning management is the personal domain of each student that is difficult to be intervened by external factors. However, Wang, Shannon and Ross [24] found that students who already had experience following online classes would tend to have more effective learning strategies and therefore, had a higher level of motivation in their online lectures. 


\subsection{Comparison of Student Satisfaction in Online Microeconomics Classes based on Differences in Digital Management Platform}

Homogeneity test results with Levene's test for equality variances assumed equal variances obtain a significance of 0.361 (> 0.05), which means that the satisfaction data of class A and B students are homogeneous. Furthermore, the results of the independent t-test show the t-value of 4.494 with a significance (2-tailed) is $0.000(<0.05)$, which indicates that there is a significant difference in student satisfaction between class A and class B. These differences are presented in Table 6.

Table 6. Mean Difference in Student Satisfaction

\begin{tabular}{ccccc}
\hline Class & $\mathrm{N}$ & Mean & Std. Deviation & Std. Error Mean \\
\hline $\mathrm{A}$ & 44 & 4.2273 & .74283 & .11199 \\
\hline $\mathrm{B}$ & 44 & 3.4773 & .82091 & .12376 \\
\hline
\end{tabular}

Student satisfaction in Class A that uses varied digital platforms is higher than class B that only uses one digital platform in the learning process. Thus, H3, which states there is a difference in student engagement between online classes that use varied digital platforms and online classes that only use one digital platform, is accepted. The use of various digital platforms will make it easier for students to understand the material. This allows differences in the learning process at each meeting, which makes students less saturated and more active than using only one type of digital platform. This is because with one type of digital platform, students and lecturers has limited access to develop and improve learning strategies, so student satisfaction is difficult to achieve.

These results are in line with the results of Lange's [25] research that media diversity resulted in high student satisfaction and showed an increase in his intention to continue using elearning. Liu, Liao and Pratt [26] said different and integrated media consisting of audio, video and text were positively correlated with perceived benefits. Sharma, Chandel and Govindaluri [27] stated the benefits of using diverse media in e-learning, one of which was to motivate students to learn more from relevant sites.

\section{Conclusion}

The findings in this study implied that variations in the use of digital platforms during the online lecture process are important points that can be optimized to increase student satisfaction and student involvement in online learning. However, not all components in student involvement can be controlled through this digital platform. The appeal to remain at home during the pandemic requires students to be more independent in learning which in fact will potentially reduce the ability of student collaboration and communication with peers. Although this can be done remotely, such as communication with video calls and working on projects online, some important points in collaboration such as personal approaches and non-verbal communication are not covered in them. The willingness of students to communicate with lecturers and their learning management is difficult to control. It is only by providing a varied digital learning platform. Therefore, the related factors that affect these indicators need to be studied further in order to optimize the benefits of online learning. 


\section{References}

[1] World Health Organization, "Coronavirus disease (COVID-19): Situation Report - 154 (Issue June)," World Health Organization, 2020. [Online]. Available: https://en.unesco.org/covid19/educationresponse/solutions.

[2] M. D. Dixson, "Creating effective student engagement in online courses: What do students find engaging?," vol. 10, no. 2, pp. 1-13, 2010.

[3] P. D. Chen, A. D. Lambert, and K. R. Guidry, "Computers \& education engaging online learners: The impact of web-based learning technology on college student engagement," Comput. Educ., vol. 54, no. 4, pp. 1222-1232, 2010.

[4] R. Junco, G. Heiberger, and E. Loken, "The effect of twitter on college student engagement and grades," J. Comput. Assist. Learn., vol. 27, pp. 119-132, 2011.

[5] E. Alqurashi, "Predicting student satisfaction and perceived learning within online learning environments," Distance Educ., pp. 1-16, 2018.

[6] M. T. Cole, D. J. Shelley, and L. B. Swartz, "Online instruction, e-learning, and student satisfaction: A three-year study," Int. Rev. Res. Open Distrib. Learn., vol. 15, no. 6, 2014.

[7] S. K. Callaway, "Implications of online learning: Measuring student satisfaction and learning for online and traditional students," Insights to a Chang. world J., vol. 2, 2012.

[8] L. C. Jackson, S. J. Jones, and R. C. Rodriguez, "Faculty actions that result in student satisfaction in online courses," J. Asynchronous Learn. Networks, vol. 14, no. 4, pp. 78-96, 2010.

[9] J. A. Gray and M. DiLoreto, "The effects of student engagement, student satisfaction, and perceived learning in online learning environments," Int. J. Educ. Leadersh. Prep., vol. 11, no. 1, 2016

[10] N. Mustafa, "Impact of the 2019-2020 Coronavirus Pandemics on Education," Int. J. Heal. Prefer. Res., 2020.

[11] M. L. Cacheiro-gonzalez, "The learning platform in distance higher education: student's perceptions," pp. 71-95, 2019.

[12] M. Kurucay and F. A. Inan, "Examining the effects of learner-learner interactions on satisfaction and learning in an online undergraduate course," Comput. Educ., 2017.

[13] R. M. Tamim, R. M. Bernard, E. Borokhovski, P. C. Abrami, and R. F. Schmid, "What Forty Years of Research Says about the Impact of Technology on Learning: A Second-Order MetaAnalysis and Validation Study," Rev. Educ. Res., vol. 81, no. 1, pp. 4-28, 2011.

[14] R. E. Clark, Learning from media: Arguments, analysis, and evidence. IAP, 2001.

[15] H. C. Cartner and J. L. Hallas, "Challenging teachers' pedagogic practice and assumptions about social media," Online Learn. J., vol. 21, no. 2, 2017.

[16] J. Lee, H. D. Song, and A. J. Hong, "Exploring factors, and indicators for measuring students' sustainable engagement in e-learning," Sustainability, vol. 11, no. 4, p. 985, 2019.

[17] Y. Luo, M. Xie, and Z. Lian, "Emotional Engagement and Student Satisfaction: A Study of Chinese College Students Based on a Nationally Representative Sample," Asia-Pacific Educ. Res., pp. 289-290, 2019.

[18] K. C. Cheong and B. Ong, "An evaluation of the relationship between student engagement, academic achievement, and satisfaction," Assess. Learn. Within Beyond Classr., p. 414, 2016.

[19] M. Chakraborty and F. M. Nufakho, "Strengthening student engagement: What do students want in online courses?," Eur. J. Train. Dev., vol. 23, no. 9, p. 782, 2014.

[20] A. Casey and B. Jones, "(2011) Using digital technology to enhance student engagement in physical education," Asia-pacific J. Heal. Sport. Phys. Educ., vol. 2, no. 2, p. 62.

[21] T. Bledsoe, Scott, and B. D. Simmerok, "A multimedia-rich platform to enhance student engagement and learning in an online environment," J. Asynchhronous Learn. Networks, vol. 17, no. 4, p. 63, 2013.

[22] J. Louder, N. Maushak, S. Crooks, S. Jones, and W. Lan, "Graduate Student's Preference toward Strong Instructor Support over Peer to Peer Collaboration in Online Courses," Proc. E-Learn 2011--World Conf. E-Learning Corp. Gov. Heal. High. Educ., pp. 730-735, 2011.

[23] R. M. Bernard et al., "A meta-analysis of three interaction treatments in distance education," Rev. Educ. Res., vol. 79, no. 3, pp. 1243-1289, 2009. 
[24] C. H. Wang, D. M. Shannon, and M. E. Ross, "Students' characteristics, self-regulated learning, technology self-efficacy, and course outcomes in online learning," Distance Educ., vol. 34, no. 3, pp. 302-323, 2013.

[25] J. C. C. H. Lange, "Vide Lectures in E-learning: Effects of Viewership and Media Learning, Satisfaction, Engagement, Interest, and Future Behavioral Intention," Intreactive Technol. Smart Educ., vol. 14, no. 1, pp. 10-11, 2017.

[26] S.-H. Liu, H.-L. Liao, and J. A. Pratt, "Impact of media richness and flow on e-learning technology acceptance," Comput. Educ., vol. 52, no. 3, pp. 599-607, 2009.

[27] S. K. Sharma, J. K. Chandel, and S. M. Govindaluri, "Students' Acceptance and Satisfaction of Learning Through Course Websites," Educ. Bus. Soc. Contemp. Middle East, vol. 3, no. 4, pp. 161-162, 2014. 